\title{
Hubungan Pengetahuan dan Sikap Perawat dengan Penatalaksanaan Pembidaian Pasien Fraktur di RS X Sulawesi Tenggara
}

\author{
Nina Nurnaningsih ${ }^{1}$ I Wayan Romantika ${ }^{1}$, Diah Indriastuti ${ }^{{ }^{*}}$ \\ ${ }^{1}$ Prodi Sarjana Keperawatan, STIKes Karya Kesehatan, Indonesia \\ nsdiahindri@gmail.com
}

\begin{abstract}
Introduction: Fracture management is performed by splinting to immobilize the part of the body that is fractured by using a device that aims to reduce and eliminate pain, prevent movement of the fracture that can cause damage to the surrounding soft tissue. The pilot study showed that nurses' knowledge was not related with attitude in managing patients with fractures. This study aims to determine the relationship between knowledge and attitudes of nurses and the management splint of fracture patients in the emergency room, Southeast Sulawesi Province in 2020.

Methods: The study was conducted using a cross sectional design method. The population were 34 nurses in a emergency room at Hospital X Southeast Sulawesi Province. A total of 34 samples were taken by total sampling.

Results: The results showed that most of the respondents had good knowledge (50.0\%), most of the respondents had good attitudes (88.2\%). There was a strong relationship between knowledge and the management of fracture patients ( $p$ value $=0.001$ and $\pi=0.569$ ), there was a strong relationship between attitude and the management of fracture patients ( $p$ value $=0.000$ and $\pi=0.622$ ).

Conclusion: Researchers suggest to nurses in emergency room always improving their knowledge, education, skills and maintain motivation in providing emergency services to patients who have fractures.
\end{abstract}

Keywords: Attitude, Fracture, Knowledge, Splinting Management.

\begin{abstract}
Abstrak
Pendahuluan: Pemahaman berupa pengetahuan dan sikap mengenai penanganan fraktur sangat diperlukan dalam penanganan fraktur untuk menyelamatkan nyawa dan mempertahankan fungsi organ dari pasien. Studi pendahuluan menunjukkan pengetahuan perawat tidak berbanding lurus dengan sikap perawat saat memberikan penanganan fraktur. Hal ini berbeda dengan hasil penelitian sebelumnya. Penelitian ini bertujuan mengetahui hubungan pengetahuan dan sikap perawat dengan penatalaksanaan pembidaian pasien di RS X Sulawesi Tenggara.

Metode: Penelitian dilaksanakan dengan metode cross-sectional design. Populasi dalam penelitian ini adalah perawat IGD Rumah Sakit X di Sulawesi Tenggara yang berjumlah sebanyak 34 orang. Sampel berjumlah 34 diambil secara total sampling.

Hasil: Hasil penelitian menunjukkan sebagian besar responden memiliki pengetahuan baik $(50 \%)$, sebagian besar responden memiliki sikap baik $(88,2 \%)$. Terdapat hubungan kuat antara pengetahuan dengan penatalaksanaan pembidaian pasien fraktur ( $p$ value $=0,001$ dan $\pi=0,569)$, ada hubungan kuat antara sikap dengan penatalaksanaan pembidaian pasien fraktur ( $p$ value $=0,000$ dan $\pi=0,622$ ).

Kesimpulan: Peneliti menyarankan kepada perawat IGD RS X untuk senantiasa meningkatkan pengetahuan, pendidikan, keterampilan dan menjaga motivasi dalam memberikan pelayanan kegawatdaruratan kepada pasien yang mengalami fraktur.
\end{abstract}

Kata kunci: Fraktur, Pengetahuan, Penatalaksanaan Pembidaian, Sikap. 


\section{PENDAHULUAN}

Peningkatan aktivitas dan mobilitas manusia sering mengakibatkan peningkatan kecelakaan dimana kecelakaan kerja dan lalu lintas merupakan penyebab utama terjadinya luka dan patah tulang (Yudhantoro \& Ismiarto, 2018). The Global Report on Road Safety 2018 yang diterbitkan oleh World Health Organization (WHO) menyatakan bahwa pada tahun 2016 insiden fraktur terbuka dilaporkan sebesar 30,7 per 100.000 orang akibat cedera dengan energi tinggi seperti crush injury (39,5\%) diikuti oleh kecelakaan lalu lintas $(34,1 \%)$ dan sekitar 1,35 juta orang atau 18,2 per 100.000 populasi di dunia meninggal dunia akibat kecelakaan lalu lintas dan negara Afrika dan Asia Tenggara paling tinggi yakni 26,6 dan 20,7 per 100.000 (World Health Organization, 2018).

Di Indonesia berdasarkan data Riskesdas 2018, jenis trauma yang dapat menyebabkan fraktur antara lain kecelakaan lalu lintas dengan kategori mengendarai sepeda motor yang paling tinggi yakni sebesar $72,7 \%$ yang didominasi kelompok umur 15-24 tahun sebesar 4,9\% dan lebih banyak terjadi pada jenis kelamin laki-laki dan daerah perkotaan dan Sulawesi Utara adalah provinsi paling tinggi terjadi kecelakaan lalu lintas dan paling terendah adalah Jambi (Kementerian Kesehatan Republik Indonesia, 2018).

Provinsi Sulawesi Tenggara urutan ke 4 secara nasional terjadinya kecelakaan lalu lintas ( Kementerian Kesehatan Republik Indonesia, 2018). Angka kecelakaan lalu lintas di Sulawesi Tenggara pada tahun 2018 terdapat 1735 kasus kecelakaan dan jumlah meninggal sebanyak 324 kasus (Direktorat Lalu Lintas Polda Sultra, 2018).

Pelayanan kegawatdaruratan yang dilakukan pada kasus fraktur adalah pembidaian yang merupakan tindakan keperawatan untuk mengistirahatkan (immobilisasi) bagian tubuh yang mengalami fraktur dengan menggunakan suatu alat yang bertujuan untuk mengurangi dan menghilangkan rasa nyeri, mencegah gerakan patah tulang yang dapat mengakibatkan kerusakan jaringan lunak sekitarnya (Smeltzer \& Bare, 2013).

Penanganan yang baik diperlukan untuk dapat mencegah kejadian cedera lebih berat pada sistem muskuloskeletal (Warouw, Kumaat, \& Pondaag, 2018). Pemahaman penolong sangat sangat diperlukan untuk dapat menolong korban baik secara primer untuk menyelamatkan nyawa maupun sekunder guna mempertahankan fungsi organ yang mengalami fraktur (Parahita \& Kurniyanta, 2013)

Penelitian sebelumnya menunjukkan bahwa pengetahuan tentang pembidaian sangat penting dimiliki oleh perawat sehingga dapat meminimalkan risiko kerusakan, sementara sikap akan menentukan bagaimana perawat memberikan tata laksana pembidaian kepada pasien fraktur, sikap positif akan membentuk tindakan positif sehingga pelaksanaan tindakan pembidaian dapat dilakukan dengan baik (Fakhrurrizal, 2015; Saputri, 2017). Semakin baik pengetahuan perawat mengenai pembidaian dan semakin positif sikap perawat dalam memberikan penanganan maka semakin baik kondisi pasien (Mardiono \& Putra, 2018; Saputri, 2017). 
Survey pendahuluan yang dilakukan peneliti di IGD Rumah Sakit X tentang pembidaian kepada 5 orang perawat diketahui bahwa 3 orang diantaranya melakukan pembidaian karena bagian yang mengalami fraktur adalah ektremitas bawah akibat kecelakaan lalu lintas. Dua orang perawat lainnya tidak melakukan pembidaian karena fraktur yang terjadi pada jari dan dianggap tidak masalah karena akan segera di bawa ke ruang operasi serta dijaga selama perjalanan dari IGD ke ruang operasi. Lima perawat menyatakan bahwa balut bidai atau pembidaian dilakukan pada pasien dengan kasus fraktur akibat kecelakaan, pembidaian ini dilakukan bertujuan menjaga agar tidak terjadi deformitas pada tulang. Pengetahuan perawat tidak berbanding lurus dengan sikap perawat saat memberikan penanganan fraktur. Tiga perawat tersebut menyatakan bahwa pembidaian harus dilakukan pada semua jenis fraktur, sementara tiga perawat lainnya mengatakan tergantung jenis frakturnya.

Penelitian ini bertujuan untuk mengetahui hubungan pengetahuan dan sikap perawat dengan penatalaksanaan pembidaian pada pasien fraktur pada Instalasi Gawat Darurat Rumah Sakit X Provinsi Sulawesi Tenggara.

\section{METODE}

Rancangan penelitian ini cross sectional study. Populasi dalam penelitian ini adalah perawat IGD Rumah Sakit X di Sulawesi Tenggara yang berjumlah sebanyak 34 orang. Jumlah sampel dalam penelitian ini adalah sebanyak 34 orang. Teknik pengambilan sampel dalam penelitian ini menggunakan teknik total sampling yaitu teknik pengambilan sampel dengan mengambil jumlah seluruh populasi untuk dijadikan sampel (Arikunto, 2013).

Instrumen penelitian berupa lembar kuisioner untuk mengukur pengetahuan dengan menggunakan skala Gutmann dan mengukur sikap dengan menggunakan skala Likert. Untuk mengukur penatalaksanaan pembidaian dilakukan dengan menggunakan lembar observasi, dimana item penilaian menggunakan SOP pembidaian dari RS X. Analisa univariat digunakan untuk frekuensi, distribusi dan proporsi dan analisa bivariate menggunakan uji Kendall's Tau-b. Penelitian ini mendapatkan izin dari Badan Penelitian dan Pengembangan Provinsi Sulawesi Tenggara dengan nomor 070/1356/Balitbang/2020.

\section{HASIL}

\section{Karakteristik Responden}

Tabel 1. Distribusi Frekuensi Berdasarkan Karakteristik Responden di IGD RS X Tahun 2020

\begin{tabular}{ccc}
\hline $\begin{array}{c}\text { Karakteristik } \\
\text { Responden }\end{array}$ & f & $\mathbf{\%}$ \\
\hline Umur (Tahun) & & \\
$21-25$ & 1 & 2.9 \\
$26-30$ & 9 & 26.5 \\
$31-35$ & 16 & 47.1 \\
$36-40$ & 8 & 23.5 \\
\hline Jenis Kelamin & & \\
Laki-Laki & 14 & 41.2 \\
Perempuan & 20 & 58.8 \\
\hline Pendidikan & & \\
DIII & 19 & 55.9 \\
S1 Ners & 15 & 44.1 \\
\hline
\end{tabular}

Tabel 1 menunjukkan bahwa sebagian besar responden berusia 31-35 tahun (47,1\%), berjenis kelamin perempuan $(55,8 \%)$ dan berpendidikan 
DIII Keperawatan sebanyak 19 orang $(55.9 \%)$.

\section{Distribusi Frekuensi Berdasarkan Variabel Penelitian}

Tabel 2. Distribusi Frekuensi Berdasarkan Variabel Penelitian di IGD RS X Sulawesi Tenggara Tahun 2020

\begin{tabular}{ccc}
\hline Variabel Penelitian & f & \% \\
\hline Pengetahuan & & \\
Baik & 17 & 50.0 \\
Cukup & 12 & 35.3 \\
Kurang & 5 & 14.7 \\
\hline Sikap & & \\
Baik & 30 & 88.2 \\
Kurang & 4 & 11.8 \\
\hline Pemasangan Bidai & & \\
Baik & 29 & 85.3 \\
Kurang & 5 & 14.7 \\
\hline
\end{tabular}

Tabel 2 menunjukkan bahwa sebagian besar responden memiliki pengetahuan baik yaitu sebanyak 27 orang (50.0\%), sebagian besar responden memiliki sikap baik (88,2\%), dan sebagian besar responden melakukan pemasangan bidai dengan baik $(85,3 \%)$.

\section{Hubungan Pengetahuan dengan Pemasangan Bidai di IGD RS $X$ Sulawesi Tenggara}

Tabel 3. Hubungan Pengetahuan dengan Pemasangan Bidai di IGD RS X Sulawesi Tenggara Tahun 2020

\begin{tabular}{|c|c|c|c|c|c|c|c|c|}
\hline \multirow{3}{*}{ Pengetahuan } & \multicolumn{4}{|c|}{ Pemasangan Bidai } & \multirow{3}{*}{ Total } & \multirow{3}{*}{$\%$} & \multirow{3}{*}{$\begin{array}{c}p \\
\text { value }\end{array}$} & \multirow{3}{*}{$\begin{array}{c}\text { koefisien } \\
\text { korelasi }\end{array}$} \\
\hline & \multicolumn{2}{|c|}{ Baik } & \multicolumn{2}{|c|}{ Kurang } & & & & \\
\hline & n & $\%$ & $\mathbf{n}$ & $\%$ & & & & \\
\hline Baik & 17 & 50,0 & 0 & 0 & 17 & 50,0 & & \\
\hline Cukup & 11 & 32,3 & 1 & 2.9 & 12 & 35,3 & & \\
\hline Kurang & 1 & 2,9 & 4 & 11,8 & 5 & 14,7 & 0,001 & 0,569 \\
\hline Total & 29 & 85,3 & 5 & 14,7 & 34 & 100 & & \\
\hline
\end{tabular}

Hasil uji Kendall's Tau- $b$ diperoleh nilai $p$ value $=0,001<\alpha=0,05$ yang menunjukkan $\mathrm{H}_{\mathrm{a}}$ diterima dan $\mathrm{H}_{\mathrm{o}}$ ditolak dan nilai koefisien korelasi 0,569 yang menunjukkan hubungan kuat, dengan Nina Nurnaningsih, dkk, Hubungan Pengetahuan dan Sikap Perawatan... Tenggara. demikian dapat disimpulkan bahwa ada hubungan kuat antara pengetahuan dengan penatalaksanaan pembidaian pasien fraktur di ruang IGD Rumah Sakit X Sulawesi

\section{Hubungan Sikap dengan Pemasangan Bidai di IGD RS X Sulawesi Tenggara}

Tabel 4. Distribusi Hubungan Sikap dengan Pemasangan Bidai di IGD RS X Sulawesi Tenggara Tahun 2020

\begin{tabular}{|c|c|c|c|c|c|c|c|c|}
\hline \multirow{3}{*}{ Sikap } & \multicolumn{4}{|c|}{ Pemasangan Bidai } & \multirow{3}{*}{ Total } & \multirow{3}{*}{$\%$} & \multirow{3}{*}{$\begin{array}{c}p \\
\text { value }\end{array}$} & \multirow{3}{*}{$\begin{array}{c}\text { koefisien } \\
\text { korelasi }\end{array}$} \\
\hline & \multicolumn{2}{|c|}{ Baik } & \multicolumn{2}{|c|}{ Kurang } & & & & \\
\hline & $\mathbf{n}$ & $\%$ & $\mathbf{n}$ & $\%$ & & & & \\
\hline Baik & 28 & 82,4 & 2 & 5,9 & 30 & 88,2 & & \\
\hline Kurang & 1 & 2,9 & 3 & 8,8 & 4 & 11,8 & 0,000 & 0,622 \\
\hline Total & 29 & 85,3 & 5 & 14,7 & 34 & 100 & & \\
\hline
\end{tabular}

Hasil uji Kendall's Tau- $b$ diperoleh nilai $p$ value $=0,000<\alpha=0,05$ yang menunjukkan $\mathrm{H}_{\mathrm{o}}$ diterima dan $\mathrm{H}_{\mathrm{a}}$ ditolak dan nilai koefisien korelasi $=0,622$ yang menunjukkan hubungan kuat. Dengan demikian dapat disimpulkan bahwa ada hubungan kuat antara sikap dengan penatalaksanaan pembidaian pasien fraktur di ruang IGD Rumah Sakit X Provinsi Sulawesi Tenggara.

\section{PEMBAHASAN}

Pengetahuan perawat terhadap penatalaksanaan pembidaian pada pasien fraktur

Hasil penelitian menunjukkan bahwa sebagian besar responden memiliki pengetahuan baik. Hal ini karena sebagian besar responden memahami dengan baik konsep pembidaian pasien fraktur dengan tepat sehingga pelaksanaannya akan dilandasi dengan pengetahuan yang mumpuni. Responden juga mengikuti pelatihan kegawatdaruratan seperti Basic Trauma Life Skill Support (BTCL), 
advance trauma life support (ATLS) yang harus dimiliki oleh responden yang bertugas di IGD yang dapat menunjang pengetahuan dan keterampilan responden.

Semakin banyak seseorang menerima informasi maka semakin banyak pula pengetahuan pada seseorang tersebut (Wawan \& Dewi, 2010). Saat individu memiliki pengetahuan yang baik maka akan membuat individu tersebut mampu menghadapi masalah yang terjadi pada diri mereka. Selain itu, responden sebagian besar adalah berusia 31-35 tahun $(47,1 \%)$ yang merupakan usia produktif sehingga dapat dengan baik dalam menerima informasi dan meningkatkan keterampilan. Semakin bertambahnya usia maka daya tangkap dan pola berfikir individu akan berkembang, sehingga penerimaan informasi pada individu tersebut juga akan semakin meningkat (Notoatmodjo, 2012). Penelitian ini sejalan dengan penelitian yang menunjukkan bahwa responden memiliki pengetahuan baik lebih banyak dibandingkan responden memiliki pengetahuan kurang tentang tentang pertolongan pertama pada pasien di IGD (Putra, 2018).

\section{Sikap perawat terhadap penatalaksanaan pembidaian pada pasien fraktur}

Hasil penelitian menunjukkan sebagian besar responden memiliki sikap baik. Responden sebagian besar menyatakan setuju dan sangat setuju dengan pernyataan-pernyataan pada kuisioner, karena dipengruhi oleh pengetahuan responden. Pengetahuan responden tentang balut bidai yang sebagian besar adalah baik akan mempengaruhi sikap dalam penatalaksanaan bidai pada pasien fraktur.

Sikap memiliki hubungan yang erat dengan pengetahuan seseorang, dimana pengetahuan yang baik akan meningkatkan kepercayaan diri individu dalam menolong korban fraktur (Azwar, 2013). Terbentuknya sikap dipengaruhi oleh dua faktor yakni faktor internal (individu itu sendiri) adalah cara individu dalam menanggapi dunia luar dengan selektif dan faktor eksternal yang distimulus dari keadaankeadaan luar untuk membentuk dan mengubah sikap seseorang (Saputri, 2017). Penelitian ini sejalan dengan penelitian yang menunjukkan bahwa sikap baik lebih besar dari sikap kurang terhadap pertolongan pertama pada fraktur (Saputri, 2017).

\section{Hubungan pengetahuan perawat dengan penatalaksanaan pembidaian pasien fraktur}

Hasil uji statistik diperoleh bahwa ada hubungan kuat antara pengetahuan dengan penatalaksanaan pembidaian pasien fraktur di ruang IGD Rumah Sakit $X$ Provinsi Sulawesi Tenggara. Adanya hubungan pengetahuan dengan pelaksanaan pembidaian pasien fraktur didukung oleh pengetahuan responden yang sebagai besar baik dan cukup dan pengetahuan ini yang mendorong responden untuk melakukan penatalaksanaan pembidaian pasien fraktur dengan baik. Selain itu, adanya clinical pathway pada pasien fraktur sebagai pedoman dalam pelaksanaan pemberian pelayanan yang melibatkan profesi lain secara tim sebagai bentuk pelayanan kesehatan yang terintegrasi, yang mendorong responden memahami dengan 
baik tindakan keperawatan secara komprehensif kepada pasien fraktur tersebut.

Hasil penelitian menunjukkan bahwa sebagian besar responden menjawab benar pada pernyataan tentang defisini balut bidai, penggunaan mitela dalam pembidaian serta komplikasi dalam pembidaian. Pemahaman responden ini diperoleh melalui pelatihan kegawatdaruratan yang pernah diikuti oleh responden, karena bertugas di IGD responden wajib harus mengikuti pelatihan kegawatdaruratan seperti BTCLS, ATLS, dan sebagainya. Pelatihan dapat meningkatkan keterampilan dan kemampuan dasar seseorang agar menghasilkan sesuatu yang lebih bernilai dengan lebih cepat (Listiana, Effendi, \& Oktarina, 2019).

Pengalaman kerja responden juga dapat mempengaruhi pengetahuan responden. Pengalaman memiliki peran penting dalam mendidik seseorang untuk berpikir dan bertindak sesuai dengan apa yang pernah terjadi sebelumnya. Seseorang memiliki pengalaman yang kurang maka pengetahuan yang dimiliki juga akan kurang.

Penelitian ini sejalan dengan penelitian yang menunjukkan bahwa terdapat hubungan pengetahuan dengan pelaksanaan pembidaian pada pasien fraktur (Mardiono \& Putra, 2018). Pengetahuan dan keterampilan balut bidai dapat ditingkatkan melalu pendidikan kesehatan (Listiana et al., 2019; Sentoso, Ibnu, \& Windartik, 2018).

Hubungan sikap perawat dengan
penatalaksanaan pembidaian pasien
fraktur

Hasil penelitian menunjukkan bahwa ada hubungan kuat antara sikap dengan penatalaksanaan pembidaian pasien fraktur di ruang IGD Rumah Sakit X Provinsi Sulawesi Tenggara. Adanya hubungan sikap dengan penatalaksanaan bidai karena didukung oleh sebagian besar responden memiliki sikap baik sesuai SOP secara individu maupun secara tim berdasarkan clinical pathway yang telah ditetapkan. Selain itu, responden juga sebagian besar berpengetahuan baik tentang penatalaksanaan bidai yang turut mendorong pembentukan sikap yang baik pula terhadap pelaksanaan bidai pada pasien fraktur di IGD. Sebagian besar perawat yang memiliki sikap baik sudah melakukan pelaksanaan bidai dengan baik. Hasil penelitian sesuai dengan teori yang menyatakan bahwa sikap merupakan faktor yang mempengaruhi perilaku seseorang dan seseorang yang mempunyai sikap positif seharusnya dapat bersikap baik (Sarwono, 2012). Pemahaman perawat tentang teknik pembidaian yang benar akan sangat berpengaruh dalam pelaksanaan pembidaian di lapangan atau di rumah sakit (Saputri, 2017).

Perawat harus mempunyai dorongan untuk mengerti dengan suatu tindakan, dengan pengalamannya untuk memperoleh pengetahuan. Elemen-elemen dan pengalaman yang tidak konsisten dengan apa yang diketahui perawat akan disusun kembali dan diubah sedemikian rupa untuk menjadi konsisten. Ini menunjukkan tentang pengetahuan tindakan perawat terhadap sikap perawat karena sikap merupakan reaksi atau respon yang masih tertutup dari seseorang terhadap suatu stimulus atau objek (Azwar, 2013; Notoatmodjo, 2012). 
Penelitian ini sejalan dengan penelitian yang dilakukan oleh Saputri (2017) yang menunjukkan bahwa ada hubungan sikap dengan pertolongan pertama fraktur. Mardiono dan Putra (2018) menunjukkan bahwa ada hubungan sikap perawat dengan penatalaksaan pembidaian pada pasien fraktur.

\section{KESIMPULAN DAN SARAN}

Penelitian ini menyimpulkan bahwa terdapat hubungan kuat antara pengetahuan dan sikap dengan penatalaksanaan pembidaian pasien fraktur di ruang IGD Rumah Sakit X Provinsi Sulawesi Tenggara. Peneliti menyarankan kepada pihak RS X agar dapat senantiasa selalu meningkatkan keterampilan perawat IGD dengan cara memfasilitasi pelatihanpelatihan kegawatdaruratan demi terciptanya pelayanan gawat darurat yang professional, efisien dan efektif khususnya pelayanan gawat darurat pasien fraktur dan kepada perawat IGD RS $\mathrm{X}$ untuk senantiasa meningkatkan pengetahuan, pendidikan, keterampilan dan menjaga motivasi dalam meningkatkan pelayanan.

\section{DAFTAR PUSTAKA}

Arikunto, S. (2013). Metodologi penelitian, suatu pengantar pendidikan. Jakarta: Rineka Cipta.

Azwar, S. (2013). Sikap manusia teori dan pengukurannya. Yogyakarta: Pustaka Pelajar.

Direktorat Lalu Lintas Polda Sultra. (2018). Data kecelakaan lalu lintas tahun 2018. Kendari: Tidak dipublikasikan.

Fakhrurrizal, A. (2015). Pengaruh pembidaian terhadap penurunan rasa nyeri pada pasien fraktur tertutup di Ruang IGD Rumah Sakit Umum
Daerah A. M. Parikesit Tenggarong. Jurnal Ilmu Kesehatan, 3(2), 1-10. doi: 0.1017/CBO9781107415324.004.

Kementerian Kesehatan Republik Indonesia. (2018). Hasil utama riset kesehatan dasar. Diperoleh dari https://kesmas.kemkes.go.id/assets/up load/dir 519d41d8cd98f00/files/Hasil -riskesdas-2018_1274.pdf.

Listiana, D., Effendi, \& Oktarina, A. R. (2019). Pengaruh pelatihan balut bidai terhadap pengetahuan dan keterampilan siswa/i Palang Merah Remaja (PMR) di SMA N. 4 Kota Bengkulu. CMHK Nursing Scientific Journal, 3(2), 145-156.

Mardiono, S., \& Putra, H. T. (2018). Hubungan pengetahuan dan sikap perawat dalam penatalaksanaan pembidaian pasien fraktur di RS Bhayangkara Palembang 2018. Jurnal Kesehatan Saelmakers Perdana, 1(2), 64-70.

Notoatmodjo, S. (2012). Promosi kesehatan dan perilaku kesehatan. Jakarta: Rineka Cipta.

Parahita, P. S., \& Kurniyanta, P. (2013). Penatalaksanaan kegawatdaruratan pada cedera fraktur ekstrimitas. EJurnal Medika Udayana, 2(9), 15971615.

Putra, G. M. (2018). Hubungan pengetahuan dan lama kerja perawat dengan penatalaksanaan pertolongan pertama pada pasien vulnus laceratum di IGD Puskesmas Maek Kecamatan Bukik Barisan Kabupaten Lima Puluh Kota. Stikes Perintis Padang.

Saputri, R. (2017). Hubungan tingkat pengetahuan balut bidai dengan sikap pertolongan pertama fraktur pada mahasiswa keperawatan. Universitas Muhammadiyah Yogyakarta. 
Sarwono, S. W. (2012). Psikologi umum. Jakarta: Rineka Cipta.

Sentoso, A. B., Ibnu, F., \& Windartik, E. (2018). Pengaruh pendidikan kesehatan tentang balut bidai terhadap pengetahuan siswa dalam melakukan pembalutan dan pembidaian di SMPN 1 Bangsal Kabupaten Mojokerto. Jurnal Penelitian S1 Keperawatan, 17.

Smeltzer, S. C., \& Bare, B. G. (2013). Buku ajar keperawatan medical bedah. Jakarta: EGC.

Warouw, J. A., Kumaat, L. T., \& Pondaag, L. (2018). Pengaruh pendidikan kesehatan dan simulasi terhadap pengetahuan tentang balut bidai pertolongan pertama fraktur tulang panjang pada siswa Kelas X SMK Negeri 6 Manado. Ejournal Keperawatan, 6(1), 1-8.

Wawan, A., \& Dewi, M. (2010). Teori dan pengukuran pengetahuan, sikap dan perilaku manusia. Yogyakarta: Nuha Medika.

World Health Organization. (2018). Global status report on road. Diperoleh dari https://www.who.int/publications/i/ite $\mathrm{m} / 9789241565684$

Yudhantoro, L., \& Ismiarto, Y. D. (2018). Gambaran angka kejadian cedera penyerta pada fraktur skapula di RS Dr Hasan Sadikin Bandung periode Januari 2014 - Desember 2018. Jurnal Kesehatan Mesencephalon, 4(38), 154-158. 